Tarih Kültür ve Sanat Araştırmaları Dergisi

Revue des Recherches en Histoire Culture et Art

مجلة البحوث التاريخية و الثقافية والفنية
Vol. 6, No. 6, December 2017

Copyright (C) Karabuk University

http://kutaksam.karabuk.edu.tr

\title{
DOI: 10.7596/taksad.v6i6.1356
}

Citation: Sevinç, M. (2017). Klasik Türk Mûsikîsinin Temel Sazlarından Neyde Basit Göçürme (Şed)

Teknikleri. Journal of History Culture and Art Research, 6(6), 613-627. doi:http://dx.doi.org/10.7596/taksad.v6i6.1356

\section{Klasik Türk Mûsikîsinin Temel Sazlarından Neyde Basit Göçürme (Şed) Teknikleri}

\section{Simple Transposition Techniques in the Nay, Which is Among the Basic Instruments of Classical Turkish Music}

Muhammet Sevinç ${ }^{1}$

\begin{abstract}
Nay (red flute), the instrument of music, is one of the main instruments of Turkish classical music and especially religious music for centuries. In this article, we will provide information about history and shape of nay and some simple techniques regarding transposing. In terms of execution, this advanced technique is important to use the instrument effectively by moving a collection of notes up or down in pitch by a constant interval. Thus we explained a few of Turkish music modes for convenience. By transposing some music notes, this study helps for music students and nay players. The article provides some examples of transposed works in its appendix as well.
\end{abstract}

Keywords: Nay, Transpose, Turkish music, Organology, Nay method.

\footnotetext{
${ }^{1}$ Ankara Üniversitesi İlahiyat Fakültesi, Turkey. E-mail: msevinc@ankara.edu.tr
} 
Ney sazı, yüzyıllardır klasik Türk mûsikîsinin ve özellikle Türk din mûsikîsinin en temel çalgılarından birisi olmuştur. Bu makalede ney sazının tarihi ve yapısı hakkında bazı kısa bilgiler verilip icra açısından basit göçürme tekniklerine dair örnekler incelenmiştir. Şed veya göçürme de denilen bu teknik hemen her sazda icrada ileri seviyeye geçme ve sazı yenme açısından önem arz eder. Bu sebeple çalışmamızda, Türk mûsikîsi makamlarından birkaç tanesini başka perdelere göçürerek sazendelere kolaylık sağlamayı amaçladık. Örnek diziler ve ek bölümde verilen eserler kız neyde icra edildiğinde bolahenk nısfiye, mansur neyde icra edildiğinde ise süpürde akordu elde edilecektir.

Anahtar kelimeler: Ney, Göçürme, Türk Mûsikîsi, Organoloji, Ney Metodu.

\section{Giriş}

İnsanoğlunun ortak dili diyebileceğimiz mûsikî; insanın sevinç, üzüntü, keder vb. duygularını ifade etmede kullandığı en kadim sanatlardandır. Mûsikî sanatının en önemli unsurlarından birisi, doğal çalgı olan insan sesi, diğeri de müzik yapmak için yine insanoğlu tarafından üretilmiş olan çalgılardır. Bugün elimizde kesin veriler olmamakla birlikte çalgı yapımının geçmişinin insanlık tarihinin erken dönemlerine kadar uzandığı düşünülmektedir. Türk mûsikîsinin kadim çalgılarından olan ney sazı ise; insan sesine en yakın kabul edilen ve insanoğlunun ürettiği en ilkel nefesli sazların günümüzde kullanılan halidir. (Tıraşcı, 2015, s. 67).

\section{A. Ney Sazının Tarihsel Gelişimi ve Günümüzdeki Yapısı}

\section{Ney Sazının Tarihsel Gelişimi}

Üflemeli çalgılar iki kısma ayrılmaktadır: Nefesli çalgılar ve kendinden nefesli olan çalgılar. Nefesli çalgılar da kendi içinde üç guruba ayrılır: Borular, delikli düdükler ve dilli düdükler. Ney sazı delikli düdükler sınıfına girip; her iki ucu da açık olan ve dik bir şekilde veya herhangi bir ucundan üflenerek çalınan sazlardandır (Ergüner, 2002, s. 30).

"Nây" kelimesi Farsça'da kamış anlamına gelmekte olup Türkçe'ye de bu şekilde geçmiş ve zamanla ney kelimesine dönüşmüştür. Araplarda, Farslılarda ve Türklerde benzer özellikli çalgılar için de yine bu isim kullanılmıştır. Ney üfleyen kişi "nâyî" veya "neyzen", neyzenlerden oluşan gurubu yöneten kişi ise, "sernâyî" ya da "serneyzen" adıyla anılmaktadır (Uygun, 2007, s. 68). Kaşgarlı Mahmud'un Dîvân-ı Lügati't-Türk adlı eserinden ve Genceli Nizameddin'in şiirlerinden anlaşıldığı üzere neyin farklı bir versiyonu olan çok sesli bir borunun da Nây-ı Türkî adıyla meşhur olduğu ifade edilmektedir. Günümüzde kullanılan neyden farklı bir yapıya sahip olduğu düşünülen bu sazın adı "Sürnay"dır. ${ }^{2}$ Yine ney isminin kullanılması da kadim zamanlara dayanmaktadır. Nitekim eskiden beri Türkler, üflemeli sazlara bu ismi vermiştir. Sümerlerce bu saz "ni, na, ti-gi, ka-gı" gibi isimlerle adlandırılmıştır (Ergüner, 2002, s. 29-31). Sümerce'de kullanılan "ni" ve "na" kelimelerinin zamanla ney kelimesine dönüşmüş olabileceği de ihtimal dâhilindedir (Uygun, 2007, s. 68).

Ney, mûsikîmizin neredeyse bütün çeşitlerinde kullanılabilen bir özelliğe ve ton aralığına sahip olduğu için zamanla terkedilmemiş ve günümüze kadar ulaşmış bir çalgıdır. Neyin tonundaki ahenk ve insana

\footnotetext{
${ }^{2}$ Sûr ve nây kelimelerinden gelmiştir. Hata ve Huten Türklerine mahsustur. Bir buçuk arşın, yani bir metre uzunluğundadır. Üzerinde düdük gibi delikler vardır. Başı, deve başı gibi eğridir ve kuvvetli bir sesi vardır. Konuşma dilinde değişerek zurna haline gelmiştir.
} 
hissettirdiği manevi duygular onun bilhassa dinî mûsikîmizde bir sembol haline gelmesinde etkili olmuştur (Akdoğan, 2010, s. 289).

İbn Haldun'un Mukaddimesinde, içi boş bir kamıştan yapılmış, üzerinde bir takım kurallara göre deliklerin açıldığı, parmak baskıları ile hoş sesler çıkaran ve dinleyeni şenlendiren "Şebbabe" isimli bir çalgıdan söz edilmektedir fakat bu kelime zaten Araplar arasında eskiden ney anlamında kullanılıyordu. (Tıraşcı, 2014, s. 111). Ancak günümüzde yapılan arkeoloji çalışmalarından elde edilen bulgulara göre ney sazının geçmişin daha eski dönemlere kadar gittiği anlaşılmaktadır.

İnsanlar, ilk dönemlerde ren geyiğinin parmak kemiklerinden yaptıkları düdükleri çalmaktaydı. Daha sonra yaptıkları bu düdüklere çeşitli delikler açarak ilk nefesli çalgı türünü icat etmişlerdir. Sümerler, Babiller, Asurlular bu nefesli çalgılardan olan flütü, Mısırılar ise bugün kullanılan ney sazını andıran yan flütü kullanmışlardır. (Koca, 2002, s. 182)

Sümerler tarafından M.Ö. beş binli yıllardan beri kullanıldığı düşünülse de ney sazı ile ilgili yapılan çalışmalar neticesinde tespit edilen en eski ney, M.Ö. üç bin ile M.Ö. iki bin sekiz yüz yıllarından kaldığı sanılan ve bugün Amerika'da Philadelphia Üniversitesi Müzesi'nde sergilenmektedir. Neyin o zamanlarda Sümerler tarafından çeşitli dini merasimlerde kullanıldığı, daha sonra Asya ve Orta Anadolu'da yaşayan milletlere geçtiği düşünülmektedir (Koca, 2002, s. 182). Ayrıca Türklerin de, İslâm dinini kabulünden önceki dönemlerde başta eğlence ve diğer bazı merasimlerde bu çalgıyı benimseyip kullandıkları kabul edilmektedir (Kaya, Ney Metodu, 2003, s. 10).

Uygurlara ait mabetlerin duvarlarında ud ve ney resimlerine rastlanmıştır. Doğu Türkistan ve Fergana bölgesinde de buna benzer kalıntılara ulaşılsa da, bu bulgular daha sonraki dönemlere işaret etmektedir. M.Ö. binli yıllardan sonra müziğin gelişmesiyle birlikte Sibirya bölgesinde de bu tarz nefesli çalgılar kullanılmış ancak zamanla bu çalgıların ses oktavları artırılarak geliştirilmiştir. Türkler tarafından kullanılan en eski ve en yaygın çalgı; kamış, kaval kemiği ve üflenerek ses çıkartılan içi boş boynuzdur (Koca, 2002, s. 183).

Eski Mısırlılara ve i̇brânîlere ait bazı kabartmalar, oyma resimler ve fresklerde ${ }^{3}$ de ney sazını andıran çeşitli çalgılara rastlanmıştır. Yine eski Mısır'da, Nil nehri deltasında fazlaca görülen kamış bitkisinin, bazı taş kabartmalardan anlaşıldığı üzere müzik aleti yapımında kullanıldığı düşünülmektedir (Uygun, 2007, s. 68).

İslam dininin ortaya çıktığı dönemde Araplar ney sazına benzeyen çalgıları "kussaba" diye adlandırmışlardır. Mûsikî kaynaklarında ney kelimesinin geçtiği en eski eserlerden birisi, Ya’kub b. İshak elKindî'nin (ö. 866) kaleme aldığı Kitâbü'I-Musavvitâti'I-Veteriyye Min Zâti'I-Veteri'I-Vâhid Ilâ Zâti'I-Veteri'IAşreti'l-Evtâr adlı risaledir. Bu risalede ney, "en-Nâyü’r-Rûmî Ale'z-Zukk" (Rum diyarında yaşayanların keseli neyi) şeklinde ifade edilmiştir. Burada zikredilen ney, aslında torbalı mizmar (tulum, gayda) diye bilinen çalgıdır. Ayrıca bazı kaynaklarda bu tulumun uç kısmında bulunan kamışın da ney adıyla anıldığı ifade edilmektedir (Uygun, 2007, s. 68).

Abdülkadir Merâği (ö. 1435) Şerhü'l-Edvâr adlı kitabında ney sazı ile ilgili bazı bilgiler vermiştir. Merağî eserinde, neyde yedi delik bulunduğu ve bu deliklerden üflenen nefesin şiddetine göre toplam yirmi yedi nağme elde edildiğini belirtmiştir. Yine Merağî’nin yaşadığı XV. asırda, neyin arkasındaki delik (aşîrân) bilinmekte ve şuca' adıyla anılmaktadır (Kolukırık, 2009, s. 186). Revnakoğlu'na göre ise neyin tam ortasında bulunan bu delik, ilk defa Osman Dede (ö. 1730) tarafından açılmış ve bu sebeple kendisine "Kutb-i Nâyî" lakabı verilmiştir. Ancak bu görüş, Hz. Mevlânâ (ö. 1273)'dan itibaren neyde yedi delikten söz edilmesi sebebiyle rivayetten öteye geçmemiştir (Uygun, 2004, s. 47). Neyin nasıl üflendiği ile ilgili ilk geniş bilgilere ise Seydî tarafından 1504 yılında kaleme alınan Matla' isimli eserde rastlanmaktadır (Sarı, 2012, s. 194).

\footnotetext{
${ }^{3}$ Bir çeşit duvar resmi.
} 
XVIII. yüzyılda Mustafa Ali Kevserî Efendi'nin (ö.1770?) Kevserî Mecmuası adlı eserinde, neyin deliklerinin de gösterildiği basit bir çizim bulunmaktadır. Bu çizimde neyde bulunan tüm perdeler adları ile birlikte yer almaktadır. Ayrıca eserde neyin ana dizisi de, ara sesleriyle birlikte gösterilmiştir (Popescu-Judetz, 1998, s. 20). Abdülbâkî Nâsır Dede (ö. 1821) ise; Tedkîk ü Takhik isimli eserinde, neyde bulunan perdeleri, üfleme şiddetine göre sıralamış ve bu perdeler hakkında bilgi vermiştir (Tura, 2006, s. 32-35).

Osmanlı döneminde sarayda ney sazının kullanılması XV. yüzyıldan itibaren yaygınlık kazanmıştır. Ayrıca çeşitli kaynaklarda saray cariyeleri arasında ney üfleyenlerin bulunduğu zikredilmektedir. XVII. yüzyıldan itibaren padişahların Enderun mektebine olan destek ve ilgilerinin artmasıyla Osmanlı sarayında yapılan mûsikî faaliyetleri de genişlemiştir. Yine bu dönemde Evliya Çelebi Seyahatnâme adlı eserinde ney sazı ve kullanıldığı yerler hakkında çeşitli rivayetler aktarmıştır (Sarı, 2012, s. 194).

Ney sazının mistik tarihi ile ilgili de bazı ilginç rivayetler bulunmaktadır. Ancak bu rivayetler akılla bağdaşmayan kimi hikâyelerden oluşmaktadır. Örneğin, ilk defa ney üfleyen peygamberin $\mathrm{Hz}$ Musa olduğu, Kur'ân'da Hz. Davud'a verildiği ifade edilen mizmarın gerçekte ney olduğu, Hz. Peygamber'in verdiği sırı $\mathrm{Hz}$. Ali'nin bir kuyuya anlattığı ve kuyunun civarında yetişen kamışların da bu sırdan dolayı hüzünlenip feryat ettiği, yine kesilen ve böylece sevgilisinden ayrılan kamışın bünyesindeki necasetten arınıp yandığı ve feryat ettiği gibi hikâyeler bunlardan bazılarıdır (Karahasan, 2003, s. 8).

Klasik Türk müziğinin başlıca nefesli çalgılarından birisi olan ney, İran'da ve Arap ülkelerinde de büyük ilgi görmüş, tekke mûsikîsinin en temel çalgısı olma özelliğini geçmişten günümüze muhafaza etmiştir. Neyin Türk din mûsikîsinde bu denli önemli bir yere sahip olmasında muhtemelen en önemli kişi; Mevlânâ Celâleddîn-i Rûmî'dir. Onun meşhur Mesnevî isimli eserine neyden söz ederek başlaması, halk tarafından mürşid-i kâmil kabul edilmesi, ondan sonra kurulan Mevlevîlik tarikatına mensup olan Mevlevîlerin bu saza büyük önem vermesi gibi sebeplerle, insanların ney sazına olan ilgisi artmış ve adeta Türk din mûsikîsinin bir simgesi haline gelmiştir (Karahasan, 2003, s. 8).

Mevlânâ, neyin insanı olgunlaştıran ve insan-ı kâmil mertebesine yükselten bir saz olduğunu ifade eder. Ona göre, berzah âleminde Allah'ın insanlara; "Ben sizin Rabbiniz değil miyim?" diye sorduğunda, insanların; "Evet" diye cevap vermelerine rağmen daha sonra bunu unutmasını ve farkında olmadan içten içe asıl yurduna ve yaratııısı ile buluşmaya özleme duymasını, sazlıktaki neyin koparılıp içinin boşaltılmasına, böylece diğer neylerden ve asıl yurdu olan sazlıktan ayrı düşmesine benzetir. Böylece insanın neyle buluşmasıyla birlikte, bu hasret ve duyulan acı dile gelmiş olur (Kuntman, 2003, s. 8).

\section{Ney Sazının Günümüzdeki Yapısı}

Ney, görünüş itibariyle basit bir çalgı olmasına rağmen sahip olduğu özellikleri ile icra yönünden oldukça zengin bir sazdır. Elbette her çalgıda olduğu gibi, neyi de doğru bir şekilde üfleyebilmek ve neyden istenilen sesleri elde edebilmek için üfleyecek kişinin başta müzik kulağının ve duygusunun gelişmiş olması gerekir. Haliyle Türk müziğinin kendine has tonlarını kulağı ile ayırt edemeyen ve hissedemeyen bir kişinin neyi hakkıyla üflemesi mümkün değildir (Halıcl, 1998, s. 29).

Ney, kamıştan imal edilen bir çalgıdır ve ney kamışı genellikle sıcak iklimle sahip olan sulak bölgelerde, akarsuların çevresinde ve suya yakın bölgelerde yetişir. Ülkemizde ney kamışının yetişmesine en uygun bölge ise, Akdeniz bölgesinin güneydoğusunda yer alan Antakya'nın Samandağ yöresidir. Ayrıca Aydın'ın Söke ilçesi gibi, uygun iklim ve tabiat şartlarını taşıyan bazı bölgelerde de ney yapımında kullanılan kamışlar yetişmektedir. Türkiye'nin dışında ise ney yapımına uygun kamışların yetiştiği ülkelerin başında Suriye (Şam, Halep), Lübnan ve Mısır (Kahire) gelmektedir (Ergüner, 2002, s. 32).

Ney sazı; başpâre, alt ve üst parazvâne ve kamıştan meydana gelmektedir. Başpâre, neyden ses çıkarmaya yarayan bir ağızlıktır. Geleneksel olarak manda boynuzunun veya fildişinin tornaya çekilmesi ile imal edilen 
başpârelerin yansıra günümüzde uygun maliyetinden dolayı fiber, derlin vb. plastik maddelerden üretilen başpâreler daha yaygın olarak kullanılmaktadır. Tahtadan üretilenleri de bulunmakla birlikte bu tür başpâreler ses kalitesi açısından uygun olmadığı için fazla tercih edilmemektedir. Parazvâne ise, neyin her iki ucuna takılan ve çatlamasını, kırılmasını önleyen iki bileziktir.

Kesilen ve ardından içi temizlenen kamışı üstünde uygun delikler açılarak imâl edilen ney, yapımının kolaylığı ve yapısının basit olmasından dolayı eskiden beri yaygın olarak kullanılan bir çalgıdır (Karahasan, 2003 , s. 9). Dokuz boğuma sahip olan ney kamışının üzerinde yedi adet delik bulunmaktadır. Ney imâlatında en sık karşılaşılan problem, akort bozukluğudur. Neyi imâl eden kişi ne kadar iyi bir neyzense, açtığı neyin akordu da o derece iyi olur. Neyin uzunluğu ise, açılacak ney türünün rast perdesine göre belirlenir. Neyde açılan deliklerin akordu ise şu şekilde ayarlanır: Neyin arka tarafında yer alan aşiran perdesi; neyzenin tercihi esas alınarak acemaşiran veya hüseynîaşîran olarak açıır. Neyin ön tarafındaki altı delik ise yukarıdan aşağıya; nevâ, nim hicaz, çargâh, segâh, kürdî ve dügâh şeklinde açılır (Uygun, 2004, s. 41-65).

İmâl edilen neyde şayet pestlik varsa; alt tarafından başlayarak kamış birer mm.lik ölçülerle tıraşlanır. Böylece kamışın boyu akort düzelene kadar kontrollü bir şekilde kısaltılır. Çünkü kamışın boyu kısaldıkça neyin sesi tizleşir. Eğer ki açılan kamışta tizlik varsa; bu durumda da neyin alt parazvânesi bir miktar yükseltilmelidir. Gerekmesi halinde parazvânenin içine yükseltildiği ölçüye göre kamış ilave edilir. Aynı şekilde ney kamışının boyu uzadıkça akordu da pestleşir (Kaya, Ney Metodu, 2003, s. 11).

Yirmi dört çeşit neyden ancak on altısı müzik icrasında kullanılmaktadır. Neyler türüne göre dörde ayrılır. Bunlar; ana neyler, nısfiye neyler, mabeyn neyler ve ara nısfiye neylerdir. Müzik terminolojisinde düzen ve akort anlamında kullanılan âhenk kavramı çalgıların, bilhassa ney sazının sabit bir perdeye göre düzenlenmiş halini ifade etmek için kullanılır. Osmanlı döneminden beri, toplu müzik icralarında sabit perde yüksekliğine olan intiyaç, farklı uzunluklara sahip neylerin kullanılması ile giderilmiştir. Belirli bir uzunluğa ve genişliğe sahip kamıştan imâl edilen ney, imalat sonrası sabit perdeye göre düzenlenmiş olur ve bu perdenin yüksekliğine göre de adlandırılır. Bu şekilde ney, hem hânendelere hem de sâzendelere düzen veren bir ahenk elde etmiş olur (Sanal, 1988, s. 517).

Ney çeşitleri, bunlara ait sabit perdeler ve ana neylerin yaklaşık uzunlukları ise şöyledir:

- Ana neyler: Bolahenk (re) ${ }^{4}$, davut (do), şah (si), mansur (la), kız ney (sol), müstahzen (fa), süpürde (mi).

- Nısfiye (oktav) neyler: Bolahenk nısfiye (re), davut nısfiye (do), şah nısfiye (si), mansur nısfiye (la), kız ney nısfiye (sol), müstahzen nısfiye (fa), süpürde nısfiye (mi).

- Mabeyn neyler (ara neyler): Bolahenk mabeyn (re \#), davut mabeyn (do \#), mansur mabeyn (la $\#$ ), kız ney mabeyn (sol \#), müztahzen mabeyn (fa $\#$ ).

- Ara nısfiye neyler (mabeyn nısfiye): Bolahenk mabeyn nısfiye ( $\mathrm{re}^{\#}$ ), davut mabeyn nısfiye (do \#), mansur mabeyn nısfiye (la \#), kız ney mabeyn nısfiye (sol \#), müztahzen mabeyn nısfiye (fa \#).

- Ana neylerin yaklaşık ölçüleri: Davut 950 mm., şah 880 mm., mansur 790 mm., kız ney 702 mm., müstahzen $580 \mathrm{~mm}$., bolahenk ${ }^{5}$ ise $520 \mathrm{~mm}$..

\footnotetext{
${ }^{4}$ Parantez içindeki notalar Türk mûsikîsine göre verilmiştir. Batı müziği akorduna göre ise notalar farklıdır. Örneğin kız ney Batı müziği notasına göre "si" akortludur.

${ }^{5}$ Uzunluğu sebebiyle elverişsiz olduğu için bolahenk yerine nısfiyesi tercih edilir.
} 


\section{B. Bazı Makamlara Ait Göçürülmüş Dizi Örnekleri}

Türk mûsikîsinde bir makamın dörtlü ve beşlisini, bütün bir diziyi hatta bütün bir mûsikî eserini, notaların arasındaki koma farkını bozmamak şartıyla kendi yerinden başka bir perde üzerine göçürmeye "şed" yani transpoze denir (Özkan, 2000, s. 189). Farklı bir ifadeye göre ise; bir müzik eserini, asıl makamının dizisindeki aralıkları korumak kaydı ile karar perdesinden başka bir perdeye nakletmektir (Karadeniz, 2013, s. 26). Türk mûsikîsi icrasında ney dışındaki, yaylı, mızraplı çalgılarda ve klarnette, göçürme yapmak zorunlu bir durumken, neyde böyle bir zorunluluk yoktur. Çünkü her akorda göre bir ney çeşidi üretilmiştir. Başta devlet koroları olmak üzere çeşitli Türk mûsikîsi korolarında birkaç farklı tondan icra yapılması geleneği okuyuş çeşitliliğini artırsa da, sâzendeleri göçürme yapmaya mecbur etmesi bakımından bazı zorluklara sebep olmaktadır. Batı müziğinde bu sorun, farklı nota anahtarı kullanılarak aşılmıştır. Ancak Türk mûsikîsinde sadece sol anahtarı kullanılması nedeniyle göçürme yapılması zaruri hale gelmektedir. ${ }^{6}$

Göçürme genel olarak şu şekilde yapılır: İcra edilecek eserin karar perdesi, daha önce belirlenen başka bir perde üzerine nakledilir. Eserin bestelendiği makamın dizisi dikkate alınır ve bu dizinin perdeleri arasındaki aralıklar aynen muhafaza edilir. Böylece eserde kullanılan perdelerin mukabili olan yeni perdeler tespit edilmiş olur. (Karadeniz, 2013, s. 26)

Ancak göçürme yapmanın da getirdiği bazı zorluklar vardır. Ney sazı yaklaşık üç oktavlık bir ses aralığına sahiptir. Fakat göçürme yapıldığında -ki özellikle konunun kız neyinde yerinden göçürme yapmak olduğu düşünülürse- dem (kalın) seslerin neyzeni yorması sebebiyle tiz seslerle yapılan göçürme, nota aralıklarının daralmasına sebep olmaktadır. Bundan dolayı bazen tiz bölgenin bir oktav altına inilerek devam edilmesi gerekebilir. Bu da, haliyle müzik estetiği açısından hoş olmayan bir durum ortaya çıkarabilir. Burada neyzenin mahareti, yani geçişlerdeki ustalığı ön plana çıkmaktadır. Her ney çeşidi ile bütün tonlarda göçürme yapılamaz. Çünkü Türk mûsikîsinde her makam her perdeye göçürülmez. Bir ney çeşidi ile de bütün sesleri göçürme yapmaya çalışmak doğru değildir. Kanaatimizce bu konudaki en uygun ve basit yöntem, makalede incelediğimiz şekilde yerinden için kız neyin, bir ses için ise mansur neyin veya bu sesler için tam tersinin tercih edilmesidir. Aksi durumda perdeler ve notalar göçürme yapılan neyde tam yerine denk gelmeyeceği için doğru bir şekilde üflenmemiş olur (Kaya, İstanbul, s. 224).

Çalışmamızda konuya örnek olması ve göçürme mantığııı anlaşııması için özellikle Arel sisteminde temel dizi sayılan çargâh ${ }^{7}$ ile yaygın olarak icra edilen uşşak, hicaz, bûselîk, hüseynî, zirgûleli hicaz, segâh ve hüzzam makamlarına ait göçürme örnekleri yine Arel-Ezgi-Uzdilek nazarî sistemi üzerinde gösterilecektir. Bu makamlara ait birer adet beste örneği ise makalenin sonuna eklenmiş olup uygulama açısından neyzenlere kolaylık sağlayacaktır. Bunlara ait çalışmalar ney sazına olan hâkimiyeti sağlayacağı gibi göçürme anlayışının kavranarak diğer makam şedlerinin icrasına yönelik bir yöntem aracı olacaktır.

\footnotetext{
${ }^{6}$ Ayrıca Ekrem Karadeniz' in Türk Mûsikîsinin Nazariye ve Esasları isimli kitabında, Türk mûsikîsindeki her bir perdenin başka bir perdeye transpozisyonunu kolaylaştıran bir transpoze cetveli vardır. Makalenin ana konusu olmadığı için buraya alma gereği duymadık fakat konuyu araştıranlar için faydalı olduğunu düşünerek burada belirtmek istedik.

${ }^{7}$ Türk mûsikîsinde temel dizi Arel ile birlikte Çârgâh olarak kabul edilmiş ve bu sistemi takip edenler tarafından takip edilmiştir. Türk müziğinde temel dizi konusu için bkz. (Tıraşcl, Safiyyüddin Urmevî'nin Temel Aldığı Ana Dizi Hakkında Farklı Bir Değerlendirme, 2017, s. 707-715).
} 


\section{1. Çârgâh'ta Rast Dizisi}

Rast makamı, yerinde bir rast beşlisine yine nevâda bir rast dörtlüsü ilave edilmesinden oluşmaktadır (Özkan, 2000, s. 115). Ancak rast makamı, çargâh perdesine göçürüldüğünde aşă̆ıdaki portede gösterilen dizi meydana gelmektedir.

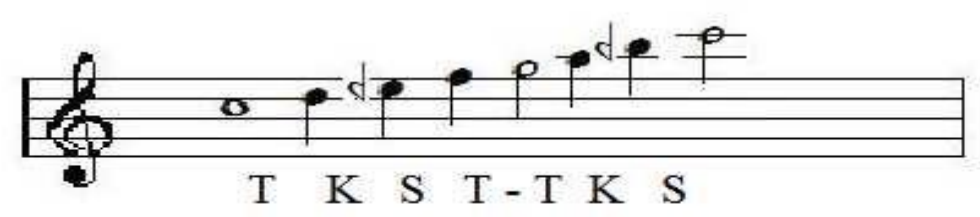

\section{Nevâ'da Uşşâk Dizisi}

Uş̧̧âk makamı ise; yerinde uşşak dörtlüsüne nevâ perdesi üzerinde bir buselik beşlisi ilave edilmesinden oluşur (Özkan, 2000, s. 120). Aynı şekilde uşşak dizisi nevâ perdesi üzerine göçürüldüğünde verdiğimiz portedeki dizi ortaya çıkmaktadır.

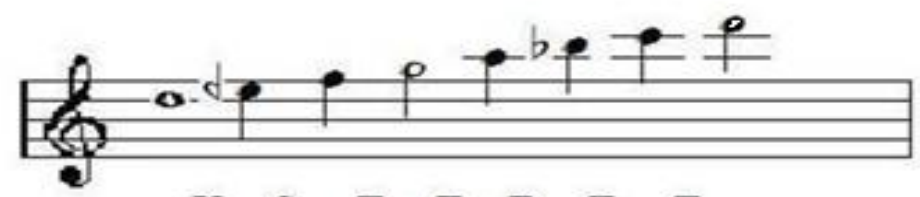

$\begin{array}{llllllllll}\mathrm{K} & \mathrm{S} & \mathrm{T} & -\mathrm{T} & \mathrm{B} & \mathrm{T} & \mathrm{T}\end{array}$

\section{Nevâ'da Hicâz Hümâyûn Dizisi}

Hicaz Hümâyûn makamı; yerinde hicaz dörtlüsüne, nevâda buselik beşlisi eklenmesinden meydana gelmektedir (Özkan, 2000, s. 134). Fakat hümâyûn dizisi nevâ perdesine göçürüldüğüne de aşağıdaki portede gösterilen dizi meydana gelmektedir.

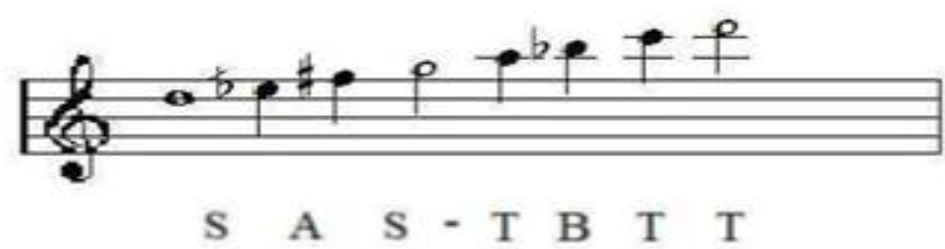




\section{Nevâ'da Buselîk Dizisi}

Bûselik makamı; yerinde buselik beşlisine hüseynîde kürdî dörtlüsü eklenerek oluşturulur (Özkan, 2000, s. 98). Buselik dizisi, nevâ perdesine göçürülmek istendiğinde de, aşağıdaki dizi meydana gelmektedir.

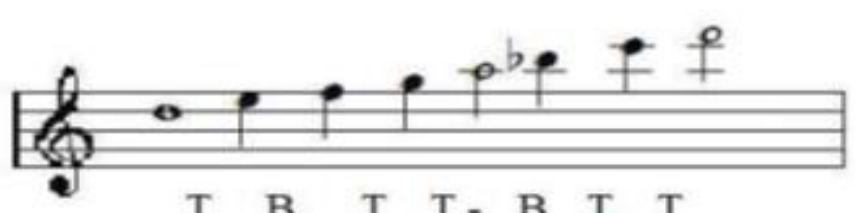

$\begin{array}{lllllll}\text { T } & \text { B } & \text { T } & \text { T }- \text { B } & \text { T } & \text { T }\end{array}$

\section{Nevâ'da Hüseynî Dizisi}

Hüseynî makamı; yerinde hüseyni beşlisine, hüseynîde uşşâk dörtlüsü ilave edilerek meydana getirilir (Özkan, 2000, s. 160). Bu dizi nevâ perdesine göçürüldüğünde de verdiğimiz portedeki dizi oluşmaktadır.

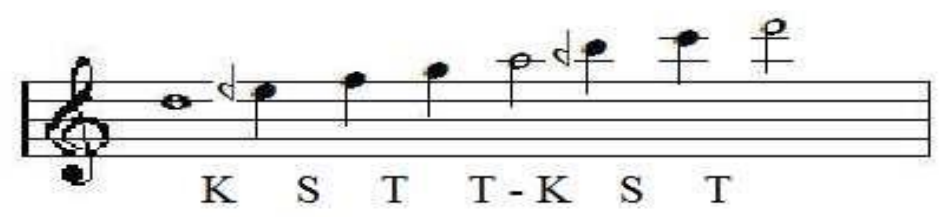

\section{Nevâ'da Zirgûleli Hicâz Dizisi}

Zirgüleli Hicâz makamı; yerinde hicâz beşlisine hüseynîde hicaz dörtlüsünün ilave edilmesinden meydana gelir (Özkan, 2000, s. 151). Bu dizi nevâ perdesine göçürülmek istenirse aşağıdaki portede gösterilen dizi ortaya çıkmaktadır.

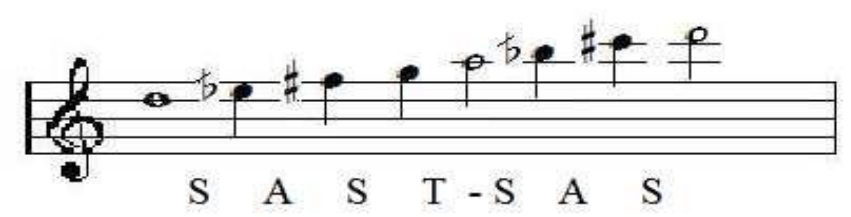

\section{Kaba Dik Hisar'da Segâh Dizisi}

Segah makamı; yerinde segâh beşlisine eviç perdesi üzerinde bir hicâz dörtlüsü eklenerek oluşturulur (Özkan, 2000, s. 276). Ancak segâh makamının dizisi tiz perdelere kadar uzanması sebebiyle dik hisar perdesi üzerine göçürülmesi durumunda porte üzerinde göstermenin zorluğundan dolayı kaba dik hisâr perdesi üzerinde gösterilmiştir. 


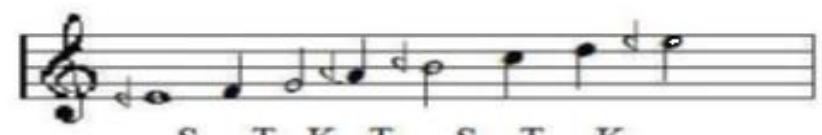

$\begin{array}{llllllllllllllll}\mathrm{S} & \mathrm{T} & \mathrm{K} & \mathrm{T} & \mathrm{S} & \mathrm{T} & \mathrm{K}\end{array}$

\section{Kaba Dik Hisar'da Hüzzam Dizisi}

Hüzzâm makamı; yerinde hüzzam beşlisine eviç perdesi üzerinde bir hicaz dörtlüsü eklenmesi ile oluşur (Özkan, 2000, s. 288). Segâh makamında olduğu gibi, hüzzâm makamının dizisi de tiz perdelere kadar uzandığından, dik hisar perdesine göçürüldüğünde porte üzerinde gösterilmesi zor olduğu için kaba dik hisâr perdesine göçürülerek gösterilmiştir.

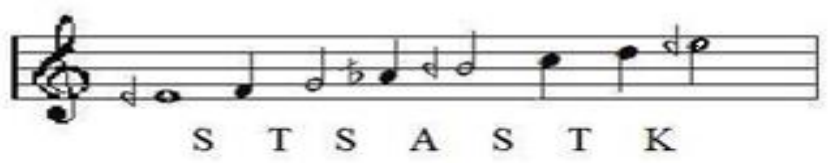

\section{Sonuç}

Değişik tondaki müzik icralarında farklı tür neylerin kullanılması ile bu sazda göçürme problemi ortadan kalkmaktadır. Ancak neyde ileri seviyede bir icra yapabilmek için neyzenin göçürme yapmayı bilmesi gereklidir. Çünkü Türk mûsikîsinde kimi zaman eserlerin içerisinde dahi farklı perdelerde küçük geçkilere şahit olunmaktadır. Örneğin, Dede Efendi (ö. 1846)'nin ferahfeza makamındaki Mevlevî Âyini'nin birinci selamında, nevâ (re) üzerine göçürülen sabâ makamı dizisini icra edebilmek için öncesinde bu tür bir çalışma yapmak gerekir. Aksi durumda neyzen bu perdelerin hakkını veremeyeceği için icrada zorlanacaktır.

Bu çalışmada, bir örnek teşkil etmesi düşüncesiyle Türk mûsikîsinde, yaygın olarak tercih edilen dizileri göçürerek, ney öğrencilerinin yapacağı göçürme çalışmalarına kaynak oluşturmaya gayret ettik. Verdiğimiz dizi örnekleri ile yapılan çalışmalarda kız neyinde (dört ses-si) bolahenk nısfiye (yerinden-mi), mansur neyde (beş ses-la) ise süpürde (bir ses-re) ahengi göçürülmüş olacaktır. Elbette bu çalışma sadece bir örnek niteliğindedir. Makalenin ek bölümünde ise bazı eser örnekleri, göçürülmüş halleri ile birlikte verilmiştir. Bu eserlerin birkaç kez geçilmesi ney sazında göçürme mantığının asgarî ölçüde kavranmasına ve çalışma etüdüne yardımcı olacağı kanaatindeyiz. Bu sebeple eserlerin temiz bir ses elde edilene kadar sabırla ve yavaş yavaş icra edilmesi gerekmektedir. 


\section{Çârgâh'ta Rast İlahi}

Ente'l-Hâdî Ente'l-Hakk

Usûl: Sofyan
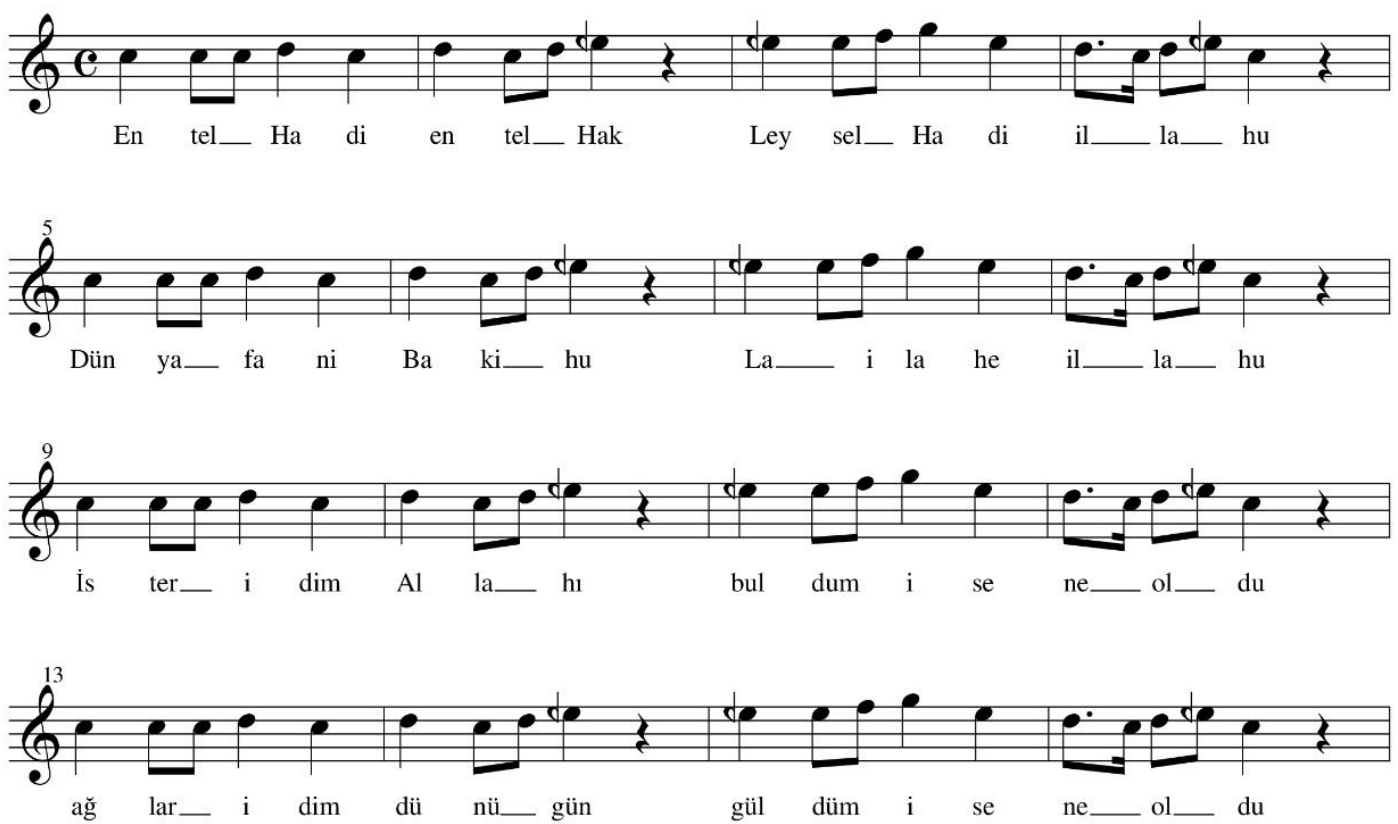

İster idim Allah'1

Buldum ise ne oldu

Ağlar idim dünü gün

Güldüm ise ne oldu
İșit Yûnus'um işit

Uş yine deli oldu

Erenler manisine

Daldım ise ne oldu 


\section{Nevâ'da Uşşak İlahi}

Hakk'ın Habîbinin Sevgili Dostu

Usûl: Sofyan

Güfte: Yûnus Emre
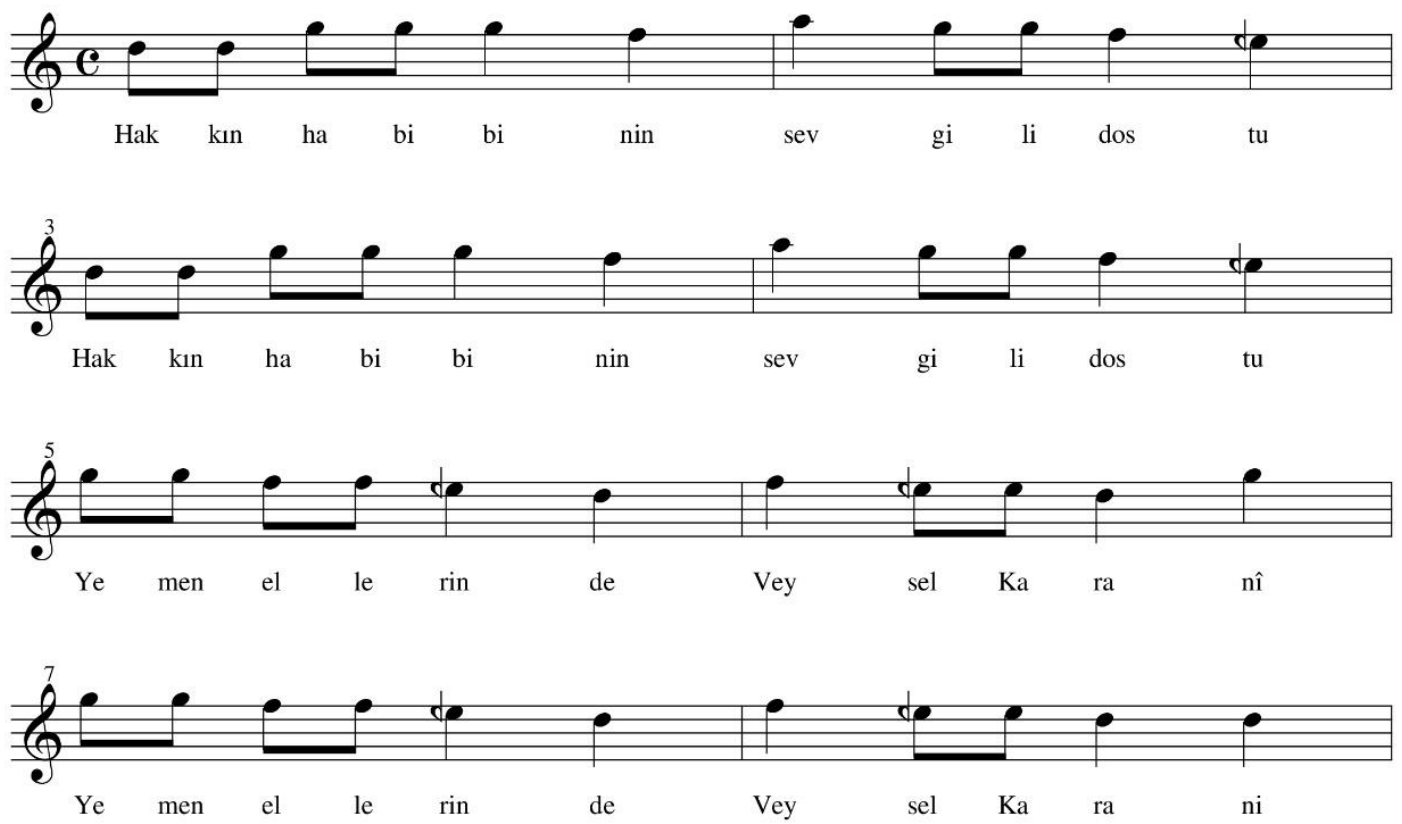

Hakk'ın Habîbinin sevgili dostu Yemen ellerinde Veysek Karanî Söylemez yalanı yemez haramı Yemen ellerinde Veysel Karanî 


\section{Nevâ'da Hicaz İlahi}

\section{Mevlam Sana Ersem Diye}

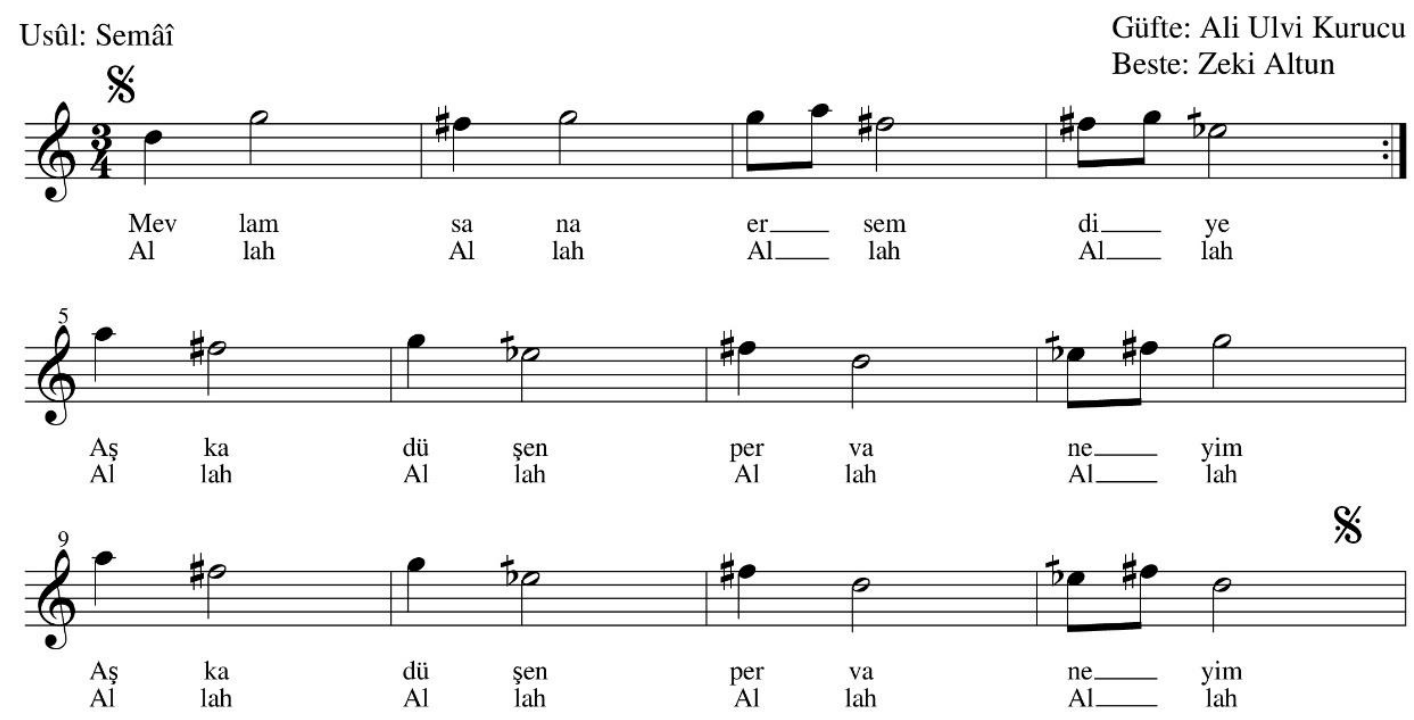

Mevlam sana ersem diye

Aşka düşen pervaneyim

Cemalini görsem diye

Aşka düşen pervaneyim 


\section{Nevâ'da Sabâ İlahi}

İsmi Sübhan Virdin mi Var

Usûl: Sofyan

Güfte: Yunus Emre
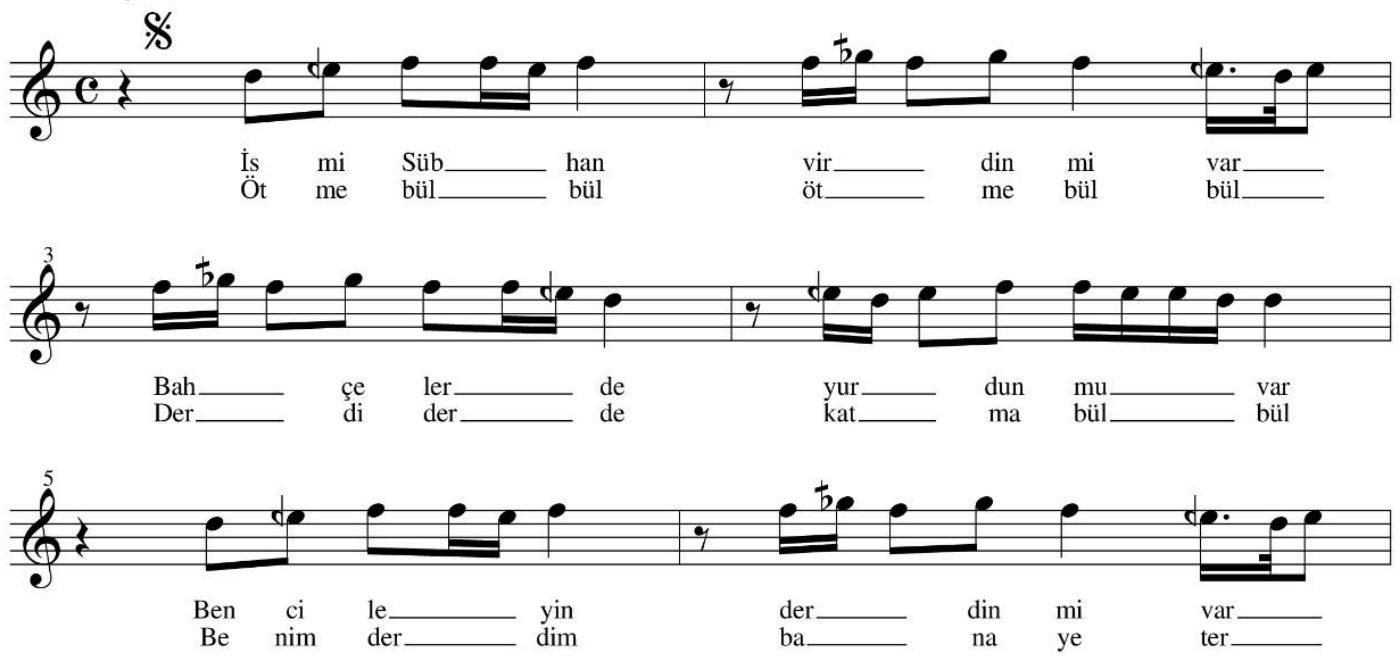

$\%$

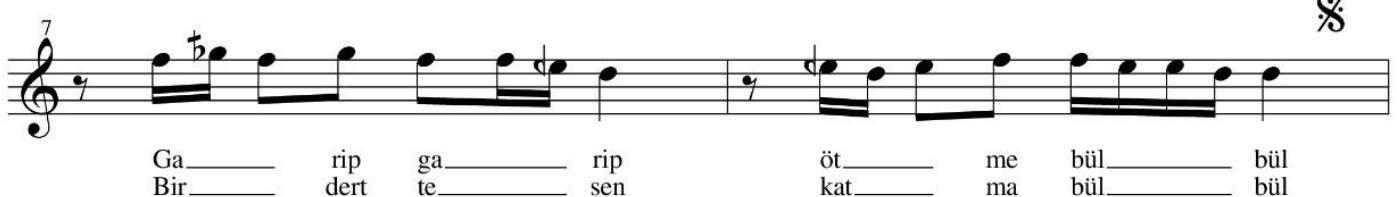

İsmi sübhan virdin mi var

Bahçelerde yurdun mu var

Bencileyin derdin mi var

Garip garip ötme bülbül

Ötme bülbül ötme bülbül

Derdi derde katma bülbül

Benim derdim bana yeter

Bir dertte sen katma bülbül 


\section{Dik Hisar'da Segâh İlahi}

Şol Cennet'in Irmakları

Usûl: Yürük Semâî
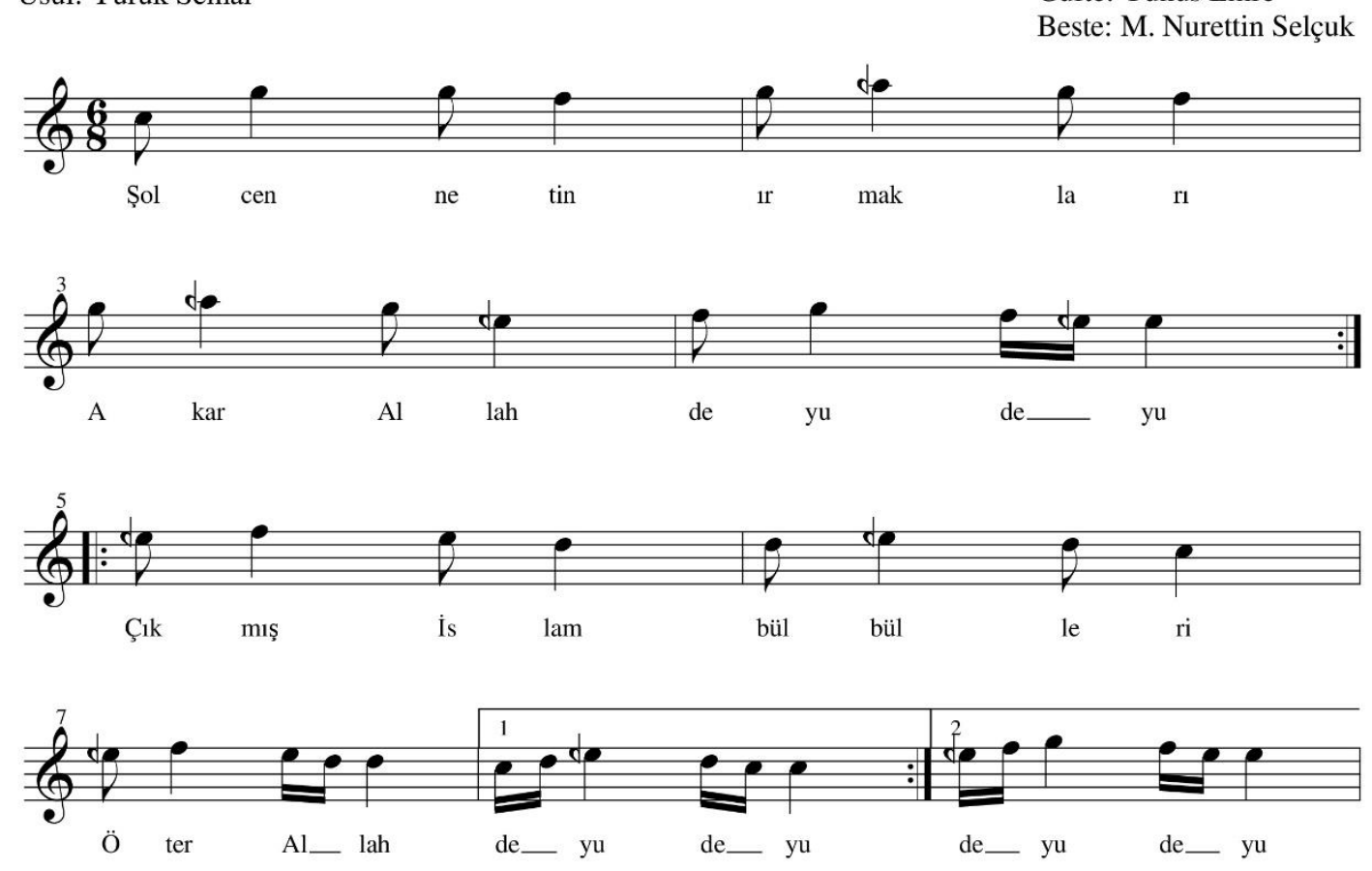

Sol Cennet'in ırmaklanı

Akar Allah deyu deyu

Çıkmıș İslam bülbülleri

Öter Allah deyu deyu

Yûnus Emre var yârine

Koma bu günü yarına

Yarın Hakk'ın divanına

Varam Allah deyu deyu 


\section{Kaynakça}

Akdoğan, B. (2010). Türk Din Musikisi Dersleri. Ankara: Bilge Ajans.

Ergüner, S. (2002). Ney Metod. İstanbul: Müzik Yayınları.

Gazimihal, M. R. (1975). Türk Nefesli Çalgıları. Ankara: Kültür Bakanlığı Milli Folklor Araştırma Dairesi.

Halıcı, F. (1998). Üstat Hayri Tümer'in Nay Metodu. Ankara: T.C. Kültür Bakanlığı Yayınları.

Karadeniz, M. E. (2013). Türk Mûsikîsinin Nazariye ve Esasları. İstanbul: Türkiye İş Bankası Kültür Yayınları.

Karahasan, H. (2003). Ney Metodu. İstanbul: Alkım Yayınları.

Kaya, A. (2003). Ney Metodu. İstanbul: Çağlar Musiki Yayınları.

Koca, F. (2002). Ney’in Tarihi Gelişimi ve Dînî Mûsikîmizdeki Yeri. Dinî Araştırmalar, IV(12), 181-196.

Kolukırık, K. (2009). Abdülkadir Meragî ve Şerhüll-Edvâr İsimli Eserinin XIV. Yüzyıl türk Musikisi Nazariyatındaki Yeri. Ankara: Ankara Üniversitesi SBE Neşredilmemiş Doktora Tezi.

Kuntman, O. (2003). Mesnevî Bazı Beyit ve Hikâyelerin Türkçe Şiir Çevirisi ve Yorumu. Ankara: Zembil Basın Yayın.

Özkan, İ. H. (2000). Türk Musikisi Nazariyatı ve Usûlleri ve Kudüm Velveleleri. İstanbul: Ötüken Yayınları.

Popescu-Judetz, E. (1998). XVIII. Yüzyıl Yazmalarından Kevserî Mecmuası Üzerine Karşılaştırmalı Bir inceleme (Çeviren ve Yayına Hazırlayan: Bülent Aksoy). İstanbul: Pan Yayıncılık.

Sanal, H. (1988). Âhenk. TDV İslam Ansiklopedisi (Cilt 1, s. 516-517). içinde İstanbul: Türkiye Diyanet Vakfı.

Sarı, A. (2012). Türk Müziği Çalgıları. İstanbul: Nota Yayıncılık.

Tıraşcı, M. (2014). "ibn Haldun'un Mukaddime'sinde Mûsikî." Cumhuriyet Üniversitesi Ilahiyat Fakültesi Dergisi, 2, 99-15.

Tıraşcı, M. (2015). "Keşfü'l-Hümûm Ve'l-Kürab Fî Şerhi Âleti't -Tarab İsimli Anonim Musiki Eserinde Çalgılar." Rast Müzikoloji Dergisi, 59-79.

Tıraşcı, M. (2017). "Safiyyüddin Urmevî’nin Temel Aldığı Ana Dizi Hakkında Farklı Bir Değerlendirme". Uluslararası Cumhuriyet Güzel Sanat Günleri Sempozyum Tam Metin Kitabı (s. 707-715). içinde Sivas: Cumhuriyet Üniversitesi Yayınları.

Tura, Y. (2006). Nâsır Abdülbâkî Dede, Tedkîk ü Tahkîk. İstanbul: Pan Yayıncılık.

Uygun, M. N. (2004). "Türk Din Mûsikîsinin Temel Sazlarından Ney ve Klasik Açkısı." Marmara Üniversitesi ilahiyat Fakültesi Dergisi, 27, 41-65.

Uygun, M. N. (2007). Ney. TDV İslam Ansiklopedisi (Cilt XXXIII, s. 68-69). içinde İstanbul: Türkiye Diyanet Vakfı. 